\title{
Horison Kemajuan Desa Menyelami Peranan Pemimpin dan Pemerintahan Desa
}

(Studi Kasus Penyelenggaraan Pemerintahan Desa Sidoasri Kecamatan Sumbermanjing Wetan Kabupaten Malang)

\section{Dhanny S. Sutopo}

Fakultas Ilmu Sosial Dan Ilmu Politik (FISIP) Universitas Brawijaya sutopo_dhanny@ub.ac.id

\section{Arief B. Nugroho}

Fakultas Ilmu Sosial Dan Ilmu Politik (FISIP) Universitas Brawijaya cakarief@ub.ac.id

\section{Nourma Yunita}

Fakultas Ilmu Sosial Dan Ilmu Politik (FISIP) Universitas Brawijaya eropapua21@gmail.com

\begin{abstract}
Abstrak Kepemimpinan merupakan proses kegiatan seseorang dalam memimpin, membimbing, mempengaruh atau mengontrol pikiran, perasaan atau tingkah laku orang. Salah satu kepemimpinan yaitu kepemimpinan Kepala Desa. Kepala desa sebagai seorang pemimpin memiliki peran yaitu mempengaruhi, memotivasi, mengerahkan, dan komunikasi. Peran kepemimpinan tersebut berhubungan dengan Tujuan Bumdes yaitu meningkatkan pendapatan desa, kebutuhan pokok desa, dan menjadikan desa sebagai desa mandiri. Penelitian ini diharapkan dapat memberikan sumbangsih pemikiran kritis terhadap gejala sosial terkait dengan ranah pemerintahan desa. Mengingat kebutuhan akan implementasi UU No 6 Tahun 2014 tentang Desa, ketika terjadi pergeseran orientasi dalam konteks pembangunan desa yang sebelumnya mengacu pada model community-driven development menjadi village-driven development.Penelitian ini dalam mendapatkan datanya menggunakan teknik Most Significant Change, yaitu dengan mengumpulkan cerita-cerita perubahan yang didapat dari berbagai anggota masyarakat yang ditunjuk secara purposive yang kemudian di klarifikasi dan dipilih dari cerita yang terkumpul melalui kelompok diskusi terfokus (FGD). Diharapkan hasil dari penelitian ini adalah berupa pendapat dari masyarakat tentang peranan pemimpin desa dan pemerintahan desa, yang dapat memberikan manfaat terhadap pembuatan kebijakan desa dan penata kelolaan pemerintahan Desa Sidoasri lebih baik.

Kata kunci : Kepemimpinan, Tata kelola desa, Partisipasi warga
\end{abstract}

\section{PENDAHULUAN}

Desa menurut undang-undang No 6 Tahun 2014 adalah desa dan desa adat atau yang disebut dengan nama lain, selanjutnya disebut Desa, adalah kesatuan masyarakat hukum yang memiliki batas wilayah yang berwenang untuk mengatur dan mengurus urusan pemerintahan, kepentingan masyarakat setempat berdasarkan prakarsa masyarakat, hak asal usul, dan/ atau hak tradisional yang diakui dan dihormati dalam sistem pemerintahan Negara Kesatuan Republik Indonesia. Desa merupakan agen pemerintah dalam pembangunan nasional. 
Era globalisasi dan reformasi seperti sekarang ini pemerintah membutuhkan otonomi daerah yang bertujuan agar masyarakat mampu menempatkan diri sejajar dengan masyarakat lain. Seperti otonomi daerah yang dimaksudkan dalam UU No. 32 Tahun 2004 tentang pemerintahan daerah yaitu hak, wewenang, dan kewajiban daerah otonom untuk mengatur dan mengurus sendiri urusan pemerintahan dan kepentingan masyarakat setempat sesuai dengan peraturan perundang-undangan. Oleh karena itu, pembangunan daerah yang berkaitan dengan pembangunan nasional tidak dapat dipisahkan dari prinsip otonomi daerah.

Merupakan agen pembangunan nasional, pemerintah harus dapat meningkatkan pembangunan daerah. Seperti yang kita ketahui, dimana Otonomi daerah menuntut untuk dapat mengatur dan mengurus sendiri urusan pemerintahan dan kepentingan masyarakat setempat. Salah satu yang dapat dilakukan untuk mendukung otonomi daerah adalah pengembangan ekonomi lokal. Menurut Blakely dan Bradshaw dalam Susanti pengembangan ekonomi lokal merupakan proses dimana pemerinta lokal dan organisasi masyarakat terlibat untuk mendorong, merangsang, memelihara, aktivitas usaha untuk menciptakan lapangan pekerjaan. Dengan pengembangan ekonomi lokal pemerintah daerah bersama masyarakat dapat mewujudkan pembangunan daerah dalam membangun ekonomi masyarakat sesuai dengan kemampuan sumber daya manusia, dan mengoptimalkan pemanfaatan sumber daya alam yang ada di daerah setempat.

Desa Sidoasri merupakan salah satu desa yang berada di wilayah pesisir Malang Selatan atau lebih tepatnya berada di Kecamatan Sumbermanjing Wetan, kabupaten Malang, Jawa Timur.Desa ini mempunyai luas wilayah sebesar 1.900 ha. Pada awalnya Desa Sidoasri merupakan pedukuhan dari Desa Tambakasri yang kemudian mengalami pemekaran Desa pada tanggal 14 Agustus 2007 yang ditetapkan oleh Bupati Malang sesuai dengan Perda No. 07 Tahun 2007. Kepala Desa pertama adalah PJS dari Kecamatan Sumbermanjing Wetan yang bernama Agus Istiwanto sampai dengan Tahun 2007.Setelah Desa Sidoasri devinitif atas pilihan masyarakat maka terpilihlah Kepala Desa yaitu Sih Reno Wibowo, yang mana hingga saat ini juga masih menjabat sebagai kepala desa.Desa Sidoasri terdiri dari 2 Dusun yaitu Dusun Tambakasri Kulon dan Dusun Tambakasri Wetan, serta terdiri dari 4 RW dan 33 RT.

Dalam kehidupan masyarakat desa yang dalam tataran normatif terdapat suatu pemerintahan desa dengan Kepala Desa yang menjadi pemimpinnya. Demikian pula yang ada di Desa Sidoasri dimana Kepala Desa dengan seluruh jajaran perangkatya semenjak desa ini berdiri pada tahun 2007 silam berupaya keras untuk memajukan desa bersama-sama masyarakatnya. Pembangunan desa sebagaimana visi Kepala Desa, melalui rencana dan pelaksanaannnya merupakan upaya pemerintah desa untuk bisa mewujudkan kesejahteraan bagi warga masyarakatnya, dimana hal ini sejalan dengan amanat UU Nomer 6/2014 tentang Desa.

Secara fisik Desa Sidoasri meskipun belum genap berumur sepuluh tahun sebagai desa mandiri, akan tetapi dalam perjalanan pembangunannya, desa ini sudah mampu paling tidak untuk melengkapi kebutuhan infrastruktur yang ada, seperti misalnya jalan, jembatan, gapuragapura RT, dan lain sebagainya.

Disisi lain dalam hal sumber daya alam, dapat kita lihat kekayaan alam Desa Sidoasri memang sangat melimpah, bentang alam yang ada seperti hutan yang lebat, perkebunan yang sangat kaya hasil alam, juga potensi lain yang ada menunjukkan bahwa Desa Sidoasri memang memiliki banyak kelebihan pada sumber daya alam. 
Komoditi hasil perkebunan yang paling menonjol adalah kopi, cengkeh, dan pisang. Hasil perkebunan ini dimanfaatkan oleh semua warga Sidoasri dan juga warga luar Sidoasri. Adapun lokasi perkebunan ini terletak di hutan yang biasanya disebut sebagai ladang tetelan. Tetelan dalam bahasa Jawa diartikan 'mengambil bagian kecil' maka secara harafiah ladang tetelan diartikan sebagai hutan yang luas diambil atau dimanfaatkan sebagian lahannya. Hampir seluruh masyarakat Sidoasri menggantungkan pemenuhan kebutuhan hidupnya di ladang tetelan ini. Maka tidak heran, apabila masyarakat Sidoasri merasa bahwa potensi yang paling besar di Desa Sidoasri adalah lahan tetelan tersebut. Lahan hutan yang dimanfaatkan oleh warga, dengan pengelolaan serta perjanjian yang jelas juga merupakan peran negara lewat Perhutani dalam memperdayakan masyarakatnya (Rosyadi, 2014).

Adapun potensi lain yang dimiliki Desa Sidoasri adalah pariwisata, beberapa diantaranya seperti Pantai Perawan, Pantai Klatakan, dan Coban Tundo Telu. Akan tetapi, potensi pariwisata tersebut memang belum banyak diketahui oleh khalayak umum, karena pada dasarnya ketiga titik pariwisata tersebut juga belum dikembangkan dan belum memiliki akses yang memadai untuk menuju lokasi wisata tersebut.

\section{METODE PENELITIAN}

Metode penelitian yang dipakai yakni dengan menggunakan konsep Kepemimpinan Desa, Tata Kelola Pemerintahan, dan Masyarakat Desa untuk menganalisisnya.

Penelitian ini juga akan melihat dan mendalami rangkaian berjalannya gambaran pembangunan Desa Sidoasri selama 2 periode kepemimpinan Kepala Desa yang masih belum tergantikan. Untuk menajamkan dan guna mendapatkan gambaran empiris akan hal ini, penelitian ini juga akan mencermati dari sudut pandang warga masyarakat untuk memastikan adanya perubahan yang paling signifikan/most significant change dirasakan oleh warga masyarakat tentang aspek yang menjadi muara dari pembangunan desa, yaitu kesejahteraan warga di Desa Sidoasri ini.

\section{HASIL DAN PEMBAHASAN}

Selama ini letak Desa Sidoasri yang berada relatif jauh dari pusat kota, memberikan dampak positif pada budaya masyarakat, yakni budaya ketimuran masih melekat kuat dalam masyarakat. Jika di pusat kota masyarakatnya sudah banyak yang hidup individual kehilangan nilai ketimurannya, maka masyarakat Desa Sidoasri dapat mempertahankan nilai-nilai tradisional tersebut yaitu sopan santun, gotong royong, dan sikap saling tolong-menolong. Akan tetapi, dengan berjalannya waktu potensi sosial ini mulai memudar karena beberapa hal, kehidupan modernitas yang mulai masuk dalam desa.Hal ini dapat terlihat dari tingkat konsumsi yang semakin tinggi.Semakin tinggi tingkat konsumsi ini memperlihatkan bahwa orang mulai hidup sendiri-sendiri untuk memenuhi kebutuhannya. Semakin seseorang berfikir hitung-hitungan dengan uang, maka seseorang itu akan memikirkan kepentingannya sendiri. Dampak jangka panjangnya adalah nilai-nilai ketimuran yang melekat akan luntur saat masyarakat mulai egois untuk hidup sendiri-sendiri.

Selain itu, salah satu perubahan yang terjadi pada aspek sosial di Desa Sidoasri yang membedakan saat ini dengan dulu adalah jumlah penduduk yang semakin bertambah banyak dan majemuk. Bisa dikatakan bahwa di Desa Sidoasri juga banyak pendatang dari luar yang kemudian tinggal dan menetap di Desa Sidoasri. Hal ini bisa terjadi juga karena salah satu faktor bahwa Sidoasri terkenal dengan keramahtamahannya dan melimpahnya sumber daya 
alam yang dimiliki. Desa yang awalnya mayoritas penduduknya beragama nasrani ini, semenjak banyak pendatang sekarang juga sudah mulai heterogen.Beberapa penduduk ada yang memeluk agama Islam, dan ada juga yang memeluk agama Hindu. Akan tetapi keberagaman ini tidak menjadikan penghalang kerukunan antarumat beragama di Desa Sidoasri.

Berdasarkan data terakhir yang dihimpun, jumlah penduduk Desa Sidoasri adalah 5230 jiwa, dengan komposisi laki-laki sejumlah 2691 orang dan perempuan 2549 orang. Dari jumlah tersebut komposisi pendudukan berdasarkan agama adalah sebagai berikut

Diagram I. Komposisi Penduduk Desa Sidoasri Berdasarkan Agama

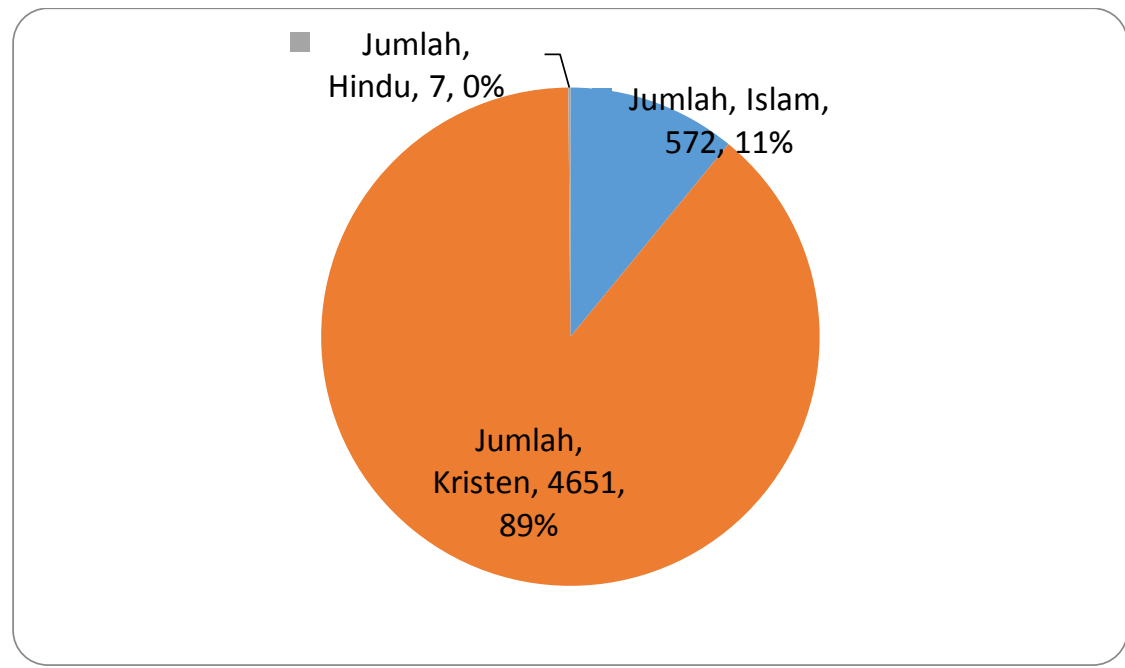

Sumber: Diolah dari Data Daftar Penduduk P4B Sidoasri

Data di atas menunjukkan bahwa mayoritas penduduk Desa Sidoasri beragama Kristen sedangkan minoritas beragama Islam dan Hindu. Atau jika diprosentasekan menjadi: Kristen $88.93 \%$, Islam $10.94 \%$, dan Hindu $0.13 \%$. Kerukunan yang mewujud hingga saat ini bagi peneliti merupakan sebuah prestasi dari pimpinan desa atau Kepala Desa dan tentu juga sikap toleransi yang telah tertanam dari seluruh penduduk desa.

Tentu persoalan atau permasalahan tidak jarang terjadi namun permasalahan tersebut masih dapat diatasi masyarakat Desa Sidoasri melalui rasa kebersamaan dan kerukunan yang merupakan keunggulan tersendiri bagi Desa Sidoasri jika dibandingkan dengan kondisi sosial desa-desa lain. Dapat dilihat bahwa sifat kerukunan masyarakat Sidoasri ini salah satunya disebabkan oleh kebiasaan berkumpul dan berkoordinasi, misalnya pada kegiatan-kegiatan desa seperti lomba peringatan kemerdekaan RI 17 Agustus ataupun kegiatan pembangunan desa, masyarakat begitu guyub dan semangat untuk saling bahu membahu membangun desa mereka. Dukungan yang diberikan masyarakat baik secara moril dan materiel juga tidak dapat dikatakan sedikit. Dalam kegiatan desa, masyarakat selalu dilibatkan, jadi tidak hanya dari pihak pemerintah saja. Masyarakat mendukung segala kegiatan yang dilakukan untuk kemajuan desa baik sumbangan tenaga maupun memberikan swadaya yang aturannya sesuai dengan kebijakan masing-masing RT. 
Perubahan sosial juga terjadi pada sikap pemuda Desa Sidoasri terkait nilai kesopanan anak sudah mulai terlihat berkurang. Hal ini dikarenakan adanya perubahan zaman membuat peradaban sedikit menurun, moralitas masyarakat ikut tergerus karena zaman semakin rumit, apa lagi dengan adanya media dan internet, seperti televisi memberikan sumbangsih besar dalam membuat moralitas menurun. Sebagai contoh, dulu jika dompet tertinggal di depan rumah selama 2 hari tidak akan hilang bahkan ada yang mengembalikan, tetapi saat ini dompet ketinggalan dan dalam keadaan terpaksa dompet bisa hilang. Itu artinya kemrosotan moral mulai terjadi di desa ini.Jadi perubahan yang paling mencolok bukan bicara tentang infrastruktur tetapi keadaan desa yang sangat rapuh.

Permasalahan kemrosotan moral sosial tidak dapat diselesaikan mulai dari desa tetapi berangkat dari keluarga terlebih dahulu.Karakter dasar dimulai dari keluarga.Jika dikaitkan dengan peran desa, bahwa desa berperan dalam mengatasi masalah ini tetapi sebagai masyarakat kita tidak bisa menuntut secara maksimal karena masyarakat harus sadar diri.Saat masyarakat tidak ikut memberikan perubahan ke arah positif maka jangan menuntut desa terlalu banyak.

Pendidikan merupakan hal yang paling penting dan tidak bisa diremehkan dalam aspek kehidupan, karena dari pendidikan lah segala kemajuan dapat diukur. Di Desa Sidoasri sendiri pun sebenarnya saat ini juga sudah terjadi perubahan yang setidaknya bisa dikatakan lebih baik lagi dari yang dulu terjadi dalam hal pendidikan. Saat ini sudah banyak warga masyarakat yang mulai sadar akan pentingnya pendidikan. Berbeda dengan dulu, yang hanya memikirkan bagaimana memenuhi kebutuhan untuk hidup sehari-hari saja. Meskipun perubahan tersebut belum begitu nampak besar karena beberapa permasalahan seperti tidak terjadi singkronisasi antara pendidikan yang diperoleh anak di sekolah, pendidikan yang diperoleh dirumah, dan lingkungan sekitar sebagai "ruang ekspresi" bagi anak.

Ketika sekolah memberikan dukungan penuh untuk semangat menempuh pendidikan, sementara lingkungan dan kondisi di rumah menuntut anak-anak untuk lebih baik bekerja saja. Hal ini juga berkaitan dengan kondisi mereka yang terlanjur hidup mapan. Untuk kebutuhan apapun orang tua sebenarnya mampu untuk memfasilitasi anak-anak mereka, akan tetapi yang disayangkan adalah tidak dibarengi dengan arahan yang baik. Sehingga anak dengan mudah menyalahgunakan fasilitas yang diberikan orang tua.

Tantangan besar kedepan yang harus dihadapi bersama adalah membuat masyarakat Sidoasri lebih sadar lagi dalam hal pendidikan yang ditempuh anak-anak mereka. Masyarakat harus menyekolahkan anaknya sampai pada jenjang yang lebih tinggi, tidak hanya berhenti pada tingkat SD atau SMP saja. Hal ini tentunya juga butuh dukungan dari berbagai pihak, salah satunya adalah pemerintah desa. Selama ini pihak desa juga turut serta, misal Pak Wiwik selaku Kepala Desa Sidoasri selalu mengingatkan warga agar menyekolahkan anak mereka. Jika anak mereka dibiarkan tidak sekolah, maka urusan administrasi di desa yang diperlukan oleh warga akan dipersulit.

Selama sepuluh tahun terakhir, memang dirasa ada perubahan. Sudah banyak yang mulai sadar pendidikan. Meskipun tidak semua warga, akan tetapi perubahan ini sudah bisa dikatakan baik daripada sebelumnya. Beberapa kendala sebenarnya terletak pada kurang tegasnya orang tua untuk mewajibkan anak menempuh pendidikan. Disisi lain sebenarnya faktor lain dalam masalah pendidikan di Desa Sidoasri ini adalah minimnya tenaga pengajar yang berkompeten dan fasilitas penunjang kegiatan belajar di sekolah itu sendiri masih belum memadai dan belum lengkap. 


\section{Perubahan Perekonomian dan Mata Pencaharian}

Dari sisi ekonomi, dapat dikatakan kondisi yang terjadi di Desa Sidoasri memang jauh lebih baik sekarang. Seperti tidak pernah kekurangan.Saat ini masyarakat sudah mulai beragam mata pencahariannya, hasil pertanian di sawah yang mereka garap mereka jual kemudian ditabung, untuk pemenuhan kebutuhan sehari-hari biasanya diperoleh dari hasil kebun.Hal ini jelas berbeda dengankondisi masa lalu, dimana hasil dari pertanian langsung dikonsumsi pribadi dan untuk memenuhi kebutuhan sendiri, sehingga masyarakat tidak memiliki tabungan.Permasalahan yang kadang terjadi seputar pertanian adalah kekeringan air dan gagal panen.

Tabel 1. Aktivitas Ekonomi Masyarakat Desa Sidoasri

\begin{tabular}{|c|c|c|c|}
\hline No & Mata Pencaharian & Jumlah & Prosentase \\
\hline 1 & Pertanian & 1428 & $50.62 \%$ \\
\hline \multirow{6}{*}{2} & Jasa/ Perdagangan & & \\
\hline & 1.Pemerintahan & 98 & $3.47 \%$ \\
\hline & \multirow{4}{*}{$\begin{array}{l}\text { 2.Jasa Perdagangan } \\
\text { 3. Jasa Angkutan } \\
\text { 4. Jasa Ketrampilan } \\
\text { 5. Jasa lainnya }\end{array}$} & 293 & $10.38 \%$ \\
\hline & & 91 & $3.22 \%$ \\
\hline & & 148 & $5.24 \%$ \\
\hline & & 212 & $7.83 \%$ \\
\hline 3 & Sektor Industri & 167 & $5.91 \%$ \\
\hline \multirow[t]{2}{*}{4} & Sektor lain & 384 & $13.61 \%$ \\
\hline & JUMLAH & 2821 & $100 \%$ \\
\hline
\end{tabular}

Sumber: Data primer 2014 diolah

Dengan melihat data di atas maka angka pengangguran di Desa Sidoasri masih cukup rendah. Jumlah tertinggi untuk jenis pekerjaan penduduk, mayoritas merupakan petani, dengan jumlah 1428 orang, atau 50,62\% dari total jumlah penduduk yang masuk dalam usia kerja.

Keberadaan lahan tetelan di Sidoasri juga memberikan perubahan yang signifikan ekonomi masyarakat. Kehidupan ekonomi masyarakat beranjak naik karena mendapat pemasukan dari hasil tetelan.Tetelan pertama kali dibuka saat pemerintahan Gus Dur dimana hasil bumi merupakan milik semua penduduk Indonesia, dari situ masyarakat mulai berani mengambil hak hutan yang sebenarnya atas hak miliki negara bukan pribadi masyarakat perseorangan. Menurut hasil wawancara yang dilakukan dengan responden, dalam mekanisme tetelan ini ada kerjasama antara masyarakat yang memiliki tetelan dengan perhutani, dimana masyarakat saat memanen hasil hutan juga memberikan retribusi kepada perhutani sebagai ganti atas tanah yang dimiliki. Retribusi ini bisa dalam bentuk hasil panen, seperti cengkeh dan kopi atau bisa juga dalam bentuk uang, retribusi ini ternyata juga bisa dinegosiasi antara masyarakat dan perhutani karena tidak adanya aturan baku yang mengatur kerjasama ini.Sumber daya alam yang dimiliki oleh Desa Sidoasri memang melimpah, salah satunya adalah dari hasil hutan tetelan yang 
dijelaskan diatas. Memang kolaborasi pemerintah (perhutani) sangat diperlukan hal ini untuk mengatasi gradasi karena alam juga karena perilaku manusia (Matose, 2008).

Setelah adanya tetelan, masyarakat yang dulu menjadi buruh sekarang sudah bisa menjadi kaya, karena sudah punya tanah sendiri. Akibatnya, permasalahan yang muncul saat ini adalah masyarakat Desa Sidoasri kebingungan dalam hal mencari tenaga kerja untuk mengerjakan tetelan.

\section{Bentuk Kepemimpinan Desa Sidoasri sebagai Upaya Kemajuan Pembangunan Desa}

Dari segi kepemimpinan desa, dimana Desa Sidoasri saat ini sudah memasuki periode kedua dengan pemerintahan Kepala Desa yang sama, tidak bisa dipungkiri bahwa ternyata memang berwujud nyata untuk kemajuan dan kesejahteraan desa. Hal ini terbukti dari beberapa tahun berjalannya Desa Sidoasri menjadi desa mandiri, kondisi fisik dan pembangunan di Desa Sidoasri terus meningkat pesat. Artinya bahwa semakin tahun semakin dirasakan manfaatnya oleh masyarakat.

Perbandingan kondisi dan lingkungan fisik Desa Sidoasri dalam kurun waktu 10-20 tahun yang lalu saat masih menjadi bagian dari Desa Tambakasri dengan saat ini, pada dasarnya memang terjadi banyak perubahan. Desa Sidoasri pada masa lalu bisa dikategorikan sebagai desa yang masih tertinggal dalam pembangunan. Berbeda halnya dengan kondisi sekarang dimana Desa Sidoasri sudah jauh berbeda dan jauh lebih baik lagi, terutama dalam hal pembangunan infrasrtuktur desa. Saat ini mulai banyak perbaikan pembangunan, misalnya pembangunan jalan, jembatan, gapura-gapura tiap RT, pendopo desa, dan berbagai infrastruktur lainnya.

Salah satu yang nampak dan menjadi sorotan warga adalah pembangunan infrastruktur desa berupa jalan. Artinya bahwa, perubahan infrastruktur berupa jalan ini dampak baiknya sangat dirasakan oleh warga masyarakat Desa Sidoasri. mengingat bahwa dulu jalan di Sidoasri sangat sulit dilalui karena terdiri dari batu-batu besar yang disusun, akan tetapi saat ini sudah dibuat menjadi rabat beton, sebagian juga sudah diaspal. Selain jalan, pembangunan lain adalah jembatan yang mulai banyak dibangun untuk kemudahan akses warga. Pembangunan banyak terjadi saat desa ini mulai pecah dengan desa Tambakasri.Istilah lainnya adalah menjadi desa mandiri.

Menanggapi perubahan fisik berupa pembangunan dan perbaikan infrastruktur di Desa Sidoasri ini jelas menyenangkan bagi seluruh warga, karena warga merasakan dampaknya secara langsung. Antara lain akses yang semakin mudah dan cepat, mobilitas juga semakin cepat.

Selain itu, perkembangan lain yang dirasakan setelah menjadi desa mandiri, ternyata banyak sekali perubahan yang lebih baik yang berguna dalam menunjang infrastruktur desa. Salah satunya adalah bantuan-bantuan kepada kelompok tani misalnya yang langsung bisa terjangkau, berbeda halnya dengan dulu saat masih bergabung dengan Desa Tambakasri. Banyak bantuan yang tidak sampai di daerah Sidoasri karena luasnya jangkauan Desa Tambakasri.

Selain keterjangkauan bantuan, perubahan yang dirasa paling signifikan yang dapat memberikan kesan beda antara kondisi dulu dengan sekarang adalah dengan dibukanya sinyal dan jaringan yang bagus oleh beberapa operator telepon seluler seperti Indosat dan XL. Tidak bisa dipungkiri bahwa sinyal dan jaringan dalam kehidupan saat ini merupakan sebuah tuntutan 
dan kebutuhan yang sangat krusial. Karena bagaimanapun juga setiap orang membutuhkan hal tersebut untuk berbagai keperntingan. Adapun beberapa manfaat yang masyarakat rasakan adalah semakin mudahnya berkomunikasi dengan kolega dan sanak saudara yang berada di luar wilayah Desa Sidoasri, pun begitu juga dengan masalaah bisnis yang semakin mudah. Hal ini jelas berbeda dengan dulu saat segala infrastruktur di Desa Sidoasri masih sangat sulit.

Akan tetapi meskipun begitu, ternyata hal tersebut tidak hanya membawa dampak positif saja bagi kelangsungan hidup dan sosial masyarakat Desa Sidoasri, ternyata penggunaan infrastruktur jaringan komunikasi yang tidak benar dan tidak diimbangi dengan kontrol sosial juga membawa dampak buruk. Hal ini erat kaitannya dengan kemerosotan nilai-nila yang terjadi di Desa Sidoasri yang akan lebih banyak di bahas dalam sub bab dinamika perubahan dan permasalahan pemuda.

Kemajuan infrastruktur desa yang dijelaskan seperti di atas pada dasarnya berkaitan erat dengan pola kepemimpinan yang ada di Desa Sidoasri. Sebagai Kepala Desa yang menjabat selama dua kali periode, sejak awal Desa Sidoasri menjadi desa mandiri hingga saat ini, sosok Kepala Desa Sidoasri memmang dirasa mumpuni dalam memimpin dan memajukan desa serta masyarakatnya. Selama pemerintahan Pak Sih Reno Wibowo sebagai Kepala Desa Sidoasri setidaknya sudah memberikan banyak perubahan positif terhadap desa, terutama setelah Desa Sidoasri menjadi desa mandiri yang lepas dari Desa Tambakasri.

Disisi lain yang juga masih berkaitan dengan kepemimpinan dan kemajuan desa, pada dasarnya kebutuhan masyarakat sudah banyak terpenuhi karena memang perencanaan pembangunan yang selama ini dilakukan merupakan hasil dari kesepakatan bersama yang memiliki tujuan memenuhi kebutuhan masyarakat. Akan tetapi memang perlu diketahui bahwa pembangunan sudah sesuai tapi belum maksimal karena pembangunan desa dilakukan secara bertahap sesuai RPJM yang disepakati, tidak mungkin pembangunan dilakukan dalam satu waktu sekaligus karena banyak pertimbangan yang harus dipikirkan.

Selanjutnya mengenai kepemimpinan antara periode pertama dan kedua banyak dirasakan oleh masyarakat bahwa mengalami peningkatan. Terlebih untuk masalah administrasi di desa, karena selama periode ke dua ini Pak Wiwik selaku kepala desa lebih banyak tinggal di desa dan banyak melayani masyarakat. Berbeda halnya ketika beliua masih menjabat dalam periode pertama dulu, beliau harus mengurus bisnis / usaha di luar desa dan hal tersebut membuat kesulitan tersendiri bagi warga masyarakat yang berkepentingan dengan Pak Wiwik karena beliau sulit di temui.

Perubahan yang terjadi di desa selama ini meliputi kerjasama antara pihak desa dengan masyarakat, pelayanan administrasi desa, hingga beberapa kegiatan seperti penyuluhanpenyuluhan yang diberikan untuk masyarakat, memang dirasa lebih baik lagi dari pada tahuntahun sebelumnya. Terutama saat Desa Sidoasri sudah menjadi desa mandiri.

Disamping itu, hubungan desa dengan lembaga agama, seperti gereja dan masjid dapat dikatakan sangat baik, contohnya dalam hal mengurus surat pernikahan. Dalam hal pernikahan gereja membutuhkan kerjasama desa mengurus surat menyurat dan desa dengan gereja mampu menjalin hubungan yang baik. Artinya desa juga turut memfasilitasi dengan baik perihal kepentingan masyarakat, terutama setelah pecah menjadi desa sendiri. Segala yang berhubungan dengan pelayanan administrasi menjadi lebih mudah untuk diurus.

Untuk kegiatan desa sendiri, saat ini juga dirasakan telah banyak perubahan yang mengarah kepada perubahan yang lebih baik. Perkembangan pembangunan yang ada di Desa Sidoasri terus mengalami peningkatan, baik secara fisik maupun sosial. Misalnya semakin tertatanya lingkungan desa karena banyak penyuluhan-penyuluhan yang dilakukan. 
Kegiatan-kegiatan penyuluhan yang diadakan oleh desa sendiri ternyata membawa perubahan yang signifikan karena diikuti dengan semakin baiknya mekanisme kerja masyarakat. Misalnya dalam hal bercocok tanam. Warga mampu membedakan bagaimana bercocok tanam yang baik dan mendapatkan keuntungan maksimal.

Dari hasil penelitian yang dilakukan, yang juga menjangkau informan-informan yang bertempat tinggal di ujung Desa Sidoasri, ternyata ditemukan beberapa hal yang berbeda dengan kebanyakan informan lain. Beberapa warga di daerah Gupit (ujung utara Desa Sidoasri) ternyata mereka tidak begitu merasakan banyak perubahan yang terjadi. Beberapa kali bantuan tidak sampai pada mereka yang tinggal di daerah ujung desa. Jika melihat letak secara geografis dimana mereka tinggal, yang memang sangat jauh dari balai desa dan pusat pemerintahan desa, meskipun hal ini tidak bisa dijadikan sebagai sebuah kesimpulan, keterjangkauan pelayanan dan kepemimpinan yang diberikan desa kepada warga masyarakatnya belum tersebar secara luas dan merata. Masih ada beberapa warga masyarakat yang nyatanya belum mendapatkan pelayanan desa. Hal ini memang bisa disebabkan berbagai faktor, jadi bukan berarti bahwa sepenuhnya kesalahan desa yang belum rata dalam menjangkau.

Keterjangkauan kepemimpinan desa juga harus disesuaikan dengan kebutuhan masyarakat.Perencanaan pembangunan yang akan disepakati oleh forum rapat diharuskan merupakan kebutuhan masyarakat, agar apa yang dilakukan memberikan manfaat bagi masyarakat Desa Sidoasri sendiri. Ketika pembangunan yang dilakukan bukan merupakan kebutuhan masyarakat akan menjadi kesia-siaan karena hanya menghabiskan anggaran desa tanpa memberikan manfaat bagi masyarakat, padahal pembangunan yang dilakukan dapat dipastikan digunakan untuk memenuhi kebutuhan masyarakat. Ada banyak pendapat tentang program yang dibutuhkan oleh masyarakat, ada informan yang menyebutkan pariwisata, pendidikan dan jiwa entrepreneur serta perbaikan infrastruktur desa.Pariwisata selama ini dianggap sebagai potensi yang dimiliki oleh desa Sidoasri tetapi sayangnya belum dikembangkan sehingga belum dapat dimanfaatkan secara maksimal oleh masyarakat.

Ketika pariwisata ini dikembangkan, maka akan membantu ekonomi masyarakat karena pariwisata dianggap sebagai tempat strategis ladang pekerjaan. Saat pariwisata akan dikembangkan ada kebutuhan-kebutuhan lain yang mengikuti untuk juga dipenuhi, seperti infrastruktur dan kesiapan mental masyarakat membuka diri pada setiap wisatawan yang datang.

Kebutuhan lainnya yaitu pendidikan, dapat kita lihat realitas di lapangan bahwa pendidikan masyarakat Desa Sidoasri masih menengah ke bawah karena minat untuk memperoleh pendidikan yang tinggi masih kurang, ini diakibatkan oleh kepentingan pemenuhan ekonomi lebih penting dibandingkan pendidikan.Masyarakat berfikir bahwa lebih menguntungkan bekerja dan mendapatkan uang daripada ke sekolah dan menghabiskan uang, tanpa berfikir jangka panjang tentang manfaat pendidikan. Kesadaran akan pendidikan yang kurang ini perlu dilakukan sosialisasi agar masyarakat memiliki kesadaran tinggi bahwa pendidikan itu penting dan berguna juga untuk memajukan Desa Sidoasri sendiri.

Kebutuhan selanjutnya dalah jiwa entrepreneur, ketika masyarakat memiliki jiwa entrepreneur juga akan membantu perekonomian untuk semakin meningkat. Kekayaan alam Desa Sidoasri yang melimpah jika digunakan secara maksimal tentu saja memberikan dampak positif bagi masyarakat, contohnya bahan mentah yang didapatkan dari alam tidak langsung dijual akan tetapi diolah terlebih dahulu. Saat bahan mental ini menjadi bahan jadi, maka nilai dari barang tersebut akan bertambah berkali-kali lipat dan memberikan masyarakat angin segar 
dalam ekonomi. Penananman jiwa entrepenur inilah yang menjadi kebutuhan paling mendasar masyarakat agar dapat mencetak masyarakat yang kreatif dan produktif.

Selanjutnya yang menjadi kebutuhan masyarakat adalah terus dilakukannya perbaikan infrastruktur desa agar aksesibilitas masyarakat mudah dan nyaman.Ketika infrastruktur desa ini baik maka secara bersamaan desa juga berubah ke arah yang lebih baik.

\section{Pihak-Pihak yang Terlibat Dalam Perubahan dan Perkembangan Desa Sidoasri}

Dalam proses perencanaan pembangunan desa, ada beberapa pihak yang terlibat dalam proses perencanaan. Pembangunan desa tidak hanya menjadi tanggung jawab desa tetapi juga kerjasama dengan beberapa pihak terkait karena program tidak akan berjalan saat dikerjakan sendiri.Masyarakat yang ikut merencanakan pembangunan masyarakat, yaitu tokoh masyarakat sesepuh desa, ketua RT, ketua RW, BPD, perangkat desa dan tokoh agama. Perwakilan ini berkumpul untuk menyampaikan aspirasi masyarakat desa dan diforumkan bersama untuk mencatat poin-poin apa saja yang menjadi kebutuhan masyarakat. Selain dari perwakilan desa, perencanaan pembangunan ini juga didukung oleh masyarakat umum terutama dalam memberikan pendapat.Masyarakat juga memiliki peran besar dalam pembangunan bukan hanya orang-orang berpangkat.

Setiap kali ada kegiatan-kegiatan desa pihak yang terlibat aktif sebagai penggerak adalah kepala desa dan LKMD. Kepala desa memiliki otoritas tinggi sehingga masyarakat Sidoasri diharapkan mampu berpartisipasi dalam kegiatan pembangunan saat kepala desa yang menyuruh langsung.

Pelaksanaan pembangunan di Desa Sidoasri bisa dikatakan pembangunan yang terbuka, artinya disini bahwa masyarakat dan pemerintah desa bersinergi bersama dalam upaya pembangunan yang lebih baik lagi bagi desa. Dalam hal perencanaan pembangunan, masyarakat juga diajak serta dalam merencanakan bagaimana Sidoasri lebih baik kedepannya. Dari seluruh jajaran aparat desa, tokoh agama, tokoh pendidikan, tokoh masyarakat, dan seluruh perwakilan tiap RT RW diundang untuk musyawarah bersama. Setelah mendapat kesepakatan, maka proyek akan dijalankan dengan proses "kemitraan" yaitu kerjasama antara masyarakat, pemerintah desa dan tidak menutup kemungkinan juga dengan pemborong.

Dalam proses pembangunan ternyata juga melibatkan masyarakat luar desa Sidoasri. Di dalam desa ada tambak udang dan sangkar burung wallet yang juga memberikan bantuan dana dalam pembangunan. Jika masyarakat luar desa mengambil dan memanfaatkan sumber daya desa Sidoasri maka kewajiban untuk membantu pembangunan desa juga ikut di dalamnya.

Dalam hal pelaksanaan kegiatan seperti pembangunan jalan atau jembatan, keterlibatan masyarakat terlihat dari swadaya yang dikeluarkan. Jadi, dana pembangunan tidak hanya berasal dari desa atau bantuan dari luar, tetapi juga swadaya masyarakat yang disesuaikan dengan kebijakan masing-masing RT, ada kebijakan yang di pukul rata untuk seluruh warga dalam lingkungan satu RT, ada juga yang disesuaikan dengan kemampuan ekonomi masingmasing warga. Selain swadaya, masyarakat juga membantu dalam hal kerja bakti membangun infrastruktur.

Kerjasama dan keterbukaan yang baik antara desa, masyarakat, dan seluruh elemen yang terlibat didalam pembangunan desa Sidoasri inilah yang menjadikan percepatan kemajuan tersendiri bagi Desa Sidosri yang nyatanya baru berumur sekitar 8 tahun sebagai desa mandiri. Beberapa kendala kecil yang ditemukan misalnya adalah sifat masyarakat yang masih "nggrundel" dan mengeluh karena tarikan swadaya, ternyata tidak menajdikan hal itu sebagai 
batu ganjalan besar. Beberapa sikap mengeluh dari masyarakat ini nyatanya juga tidak berpengaruh besar bagi masyarakat yang lain, karena mengeluh merupakan sikap yang wajar dalam keseharian. Ternyata meskipun sedikit mengeluh, masyarakat masih tetap semangat memberikan apa yang terbaik untuk desa asalkan manfaat nya dapat dirasakan oleh seluruh masyarakat itu sendiri.

Contoh kegiatan di desa yang menunjukkan bahwa masyarakat Sidoasri memang guyub dan kompak adalah pada perayaan Hari Kemerdekaan RI 17 Agustus dan Ulang Tahun Desa 25 Agustus, selain itu juga ketika ada pembangunan-pembangunan infrastruktur desa, semua masyarakat juga terlibat dalam pembangunan, baik berupa bantuan dana maupun tenaga.

Adapun peran pihak luar dalam pembangunan beberapa diantaranya adalah penguasaha sarang burung walet dan tambak udang yang memiliki ijin usaha di wilayah Desa Sidoasri. Beberapa bantuan dana dari mereka biasanya di berikan pada saat desa memiliki kegiatan atau acara seperti peringatan 17 Agustusan dan Ulang Tahun Desa.

\section{Mekanisme Perencanaan Pembangunan Desa Sidoasri}

Perencanaan pembangunan desa selalu memiliki mekanisme atau pertimbanganpertimbangan khusus, dimana diharapkan perencanaan yang akandisepakati dapat dilakukan secara maksimal dan memperkecil peluang terjadinya dampak negatif. Desa Sidoasri sendiri juga memiliki mekanisme perencaan yang ajeg, yaitu mulai dari mengumpulkan orang-orang yang memiliki kemampuan untuk membantu memikirkan pembangunan yang akan dilakukan hingga menyepakati keputusan bersama yang menjadi prioritas kebutuhan masyarakat.

Setiap perencanaan pembangunan yang akan dilakukan oleh desa merupakan hasil musyawarah bersama. Setiap ide pembangunan yang dimiliki dijabarkan, mulai dari kebutuhan masyarakat atau bukan, pendanaan, hingga proses pelaksanaannya. Ketika ide pembangunan ini dirasa menjadi kebutuhan dan bisa untuk dilakukan oleh masyarakat, maka ide tersebut menjadi kesepakatan bersama dan siap dikerjakan.

Mekanisme perencanaan pembangunan desa yang sudah disepakati seperti di atas, selanjutnyadimasukkan dalam Rencana Pembangunan Jangka Mengeah (RPJM) Desa.Diharapkan setiap ide-ide pembangunan yang sudah disepakati nantinya benar-benar dapat dilaksanakan, dengan cara memasukkan dalam RPJM Desa. Ketika ide ini sudah masuk dalam RPJM maka tanggung jawab pembangunan ini menjadi prioritas untuk bisa dilakukan.Berbeda halnya dengan ide pembangunan yang belum dimusyawarahkan dan disepakati oleh forum rapat, tidak memiliki prioritas untuk dilaksanakan.Akan tetapi menurut penuturan salah satu aparat desa, RPJM ini sewaktu-waktu bisa berubah ketika ada keadaan di luar bayangan masyarakat, seperti adanya bencana.Ketika bencana hadir di tengah-tengah masyrakat, maka program yang sebenarnya tidak masuk dalam RPJM bisa dilakukan untuk mengatasi bencana yang ada. Biasanya program tersebut diberi nama program darurat, prioritas program ini ada di atas program-program pembangunan yang ada dalam RPJM.

Dalam mekanisme perencanaan pembangunan Desa Sidoasri juga didorong oleh karakter masyarakat di dalamnya, bisa kita ambil contoh ketika masyarakat mau bekerjasama dengan pihak desa melakukan pembangunan, maka program yang ada dalam RPJM bisa dilakukan sesuai waktu yang sudah disepakati. Tetapi saat masyarakat ini enggan untuk membantu aparat desa melakukan program-program pembangunan, maka dapat dipastikan program tidak dapat berjalan karena masyarakat merupakan elemen penting dalam setiap program pembangunan. 
Ketika masyarakat antusias untuk ikut bekerjasama membangun desa kearah yang lebih baik, pembangunan berjalan tanpa hambatan. Selama ini pembangunan yang ada di Desa Sidoasri merupakan swadaya masyarakat, meskipun tidak $100 \%$ dana pembangunan di tanggung oleh masyarakat. Ketika desa memiliki dana yang belum cukup untuk melakukan pembangunan, maka kekurangan dana tersebut akan ditanggung rata oleh semua masyarakat Desa Sidoasri. Bukan hanya dana, tenagapun juga diberikan warga untuk ikut berpartisipasi dalam perencanan dan pelaksanaan pembangunan desa.

Ternyata di balik kekuatan karakter masyarakat, ada juga faktor penghambat pembangunan yang dipikirkan yaitu ketidaksesuaian waktu pelaksanaan pembangunan di lapangan dengan RPJM.Banyaknya kegiatan-kegiatan desa, seperti merayakan hari ulang tahun Republik Indonesia dan ulang tahun desa ternyata dapat menggeser prioritas program pembangunan yang berjalan. Contohnya, pembangunan pendopo di depan balai desa mengalam pemberhentian pengerjaan karena pelaksanaanya sama dengan pelaksanaan kegiatan HUT RI dan Desa.

Adapun hambatan lainyaitu masalah komunikasi. Mekanisme perencanaan pembangunan desa selama ini merupakan hasil dari forum rapat, ketika ada beberapa orang yang tidak mengikuti rapat, secara otomatis tidak Akan tahu hasil rapat apa yang sudah disepakati. Hal inilah yang seringkali menjadi sebuah masalah, tidak mengikuti rapat dan tidak setuju dengan hasil rapat yang mulai dilakukan di lapangan.Konsekuensi ketidakhadiran rapat berarti harus menerima semua keputusan forum rapat. Ketika tidak setuju, maka tidak memeliki wewenang sama sekali merubah hasil program pembangunan yang sudah disepakati.

\section{Peranan Pemimpin dan Pemerintahan Desa atas Upaya Kemajuan Desa Sidoasri}

Peranan pemimpin desa dan pemerintahan desa atas upaya kemajuan desa dimulai dari keberadaan kelompok pemuda desa Sidoasri.Hal ini ada kaitannya dengan peran dalam setiap kegiatan atau segala aspek perubahan di desa memang menjadi poin tersendiri, begitu juga dengan yang terjadi di Desa Sidoasri. Peran pemuda di Sidoasri nampak pada adanya karang taruna yang memang menjadi wadah bagi pemuda desa untuk menyalurkan segala bakat dan aspirasinya. Meskipun pada perjalanannya memang tidak semua kegiatan di dalam karang taruna ini berjalan secara teratur. Adapun beberapa kegiatan yang biasanya dilakukan oleh karang taruna adalah saat ada acara khusus di Pantai Perawan yang merupakan objek wisata desa, biasanya karang taruna mengerahkan anggotanya yang notabene adalah para pemuda untuk menajaga kemanan dan mengkoordinir penitipan kendaraan di lokasi wisata.

Desa sebagai lembaga tertinggi juga memberikan kontribusi dalam membina pemuda atau masyarakat yang membuat masalah.Sebagai contoh, saat ada masalah yang meresahkan warga, desa ikut memecahkan permasalahannya bahkan ketika masalah ini tidak terselesaikan dalam lingkup desa maka akan diteruskan ke polsek. Dari sini terlihat bahwa kepemimpinan pak Wiwik tegas dalam menyikapi permasalahan.

Selain itu, peranan kepemimpinan terlihat dari kerjasama antara pihak desa dengan masyarakat, pelayanan administrasi desa, kegiatan-kegiatan masyarakat, dan keterjangkauan pelayanan desa yang dirasakan masyarakat.Perubahan yang terjadi di desa selama ini meliputi kerjasama antara pihak desa dengan masyarakat, pelayanan administrasi desa, hingga beberapa kegiatan seperti penyuluhan-penyuluhan yang diberikan untuk masyarakat, memang dirasa lebih baik lagi dari pada tahun-tahun sebelumnya. Terutama saat Desa Sidoasri sudah menjadi desa mandiri.

Hubungan desa dengan lembaga agama, seperti gereja dan masjid itu baik, contohnya dalam hal mengurus surat pernikahan. Dalam hal pernikahan gereja membutuhkan kerjasama 
desa mengurus surat menyurat dan desa dengan gereja mampu menjalin hubungan yang baik. Artinya desa juga turut memfasilitasi dengan baik perihal kepentingan masyarakat, terutama setelah pecah menjadi desa sendiri. Segala yang berhubungan dengan pelayanan administrasi menjadi lebih mudah untuk diurus. Terlebih lagi ketika periode kedua pemerintahan Pak Wiwik. Karena pada periode pertama Pak Wiwik sering berada diluar desa untuk berbagai kepentingan sehingga masih sulit ditemui, sementara ketika periode kepemimpinan yang kedua ini lebih banyak waktunya untuk masyarakat dan lebih sering berada di desa.

\section{Most Significant Change (MSC)}

Dari seluruh perubahan yang terjadi di Desa Sidoasri, baik dalam skala desa maupun skala dua kali periode kepemimpinan Kepala Desa Sidoasri, ternyata ditemukan beberapa aspek perubahan yang dirasakan menjadi perubahan yang paling signifikan dan bisa juga disebut sebagai perubahan terbaik.Dari skala desa, sebelum desa ini menjadi desa mandiri atau masih menjadi bagian dari Desa Tambakasri hingga berubah menjadi desa mandiri dan bernama Sidoasri pada tahun 2007, ternyata banyak perubahan pada aspek fisik yang mengarah kepada perubahan yang lebih baik, terutama di bidang pembangunan dan perbaikan infrastruktur desa, seperti jalan, jembatan, dan gapura-gapura tiap RT. Sementara pada aspek sosial, perubahan terasa juga tidak lain karena dukungan dari semakin baiknya infrastruktur jalan dan jembatan tadi

Faktor pendukung perubahan signifikan yang terjadi di Desa Sidoasri sebenarnya saling terkait antara yang satu dengan yang lain. Salah satunya adalah perubahan infrastruktur seperti jalan dan jembatan sangat berpengaruh bagi kesejahteraan warga. Kemudian kesejahteraan warga yang terukur dengan peningkatan ekonomi warga ini salah satunya juga disebabkan oleh dibukanya lahan huatan tetelan.

Dari skala pemerintahan yang selama ini sudah dijalankan sebanyak dua periode dengan kepala desa yang sama, yakni Pak Wiwik, menurut beberapa penuturan masyarakat Kepemimpinan Pak Wiwik tidak bisa dipungkiri bahwa ternyata memang berwujud nyata. Terbukti dari beberapa tahun berjalannya Sidoasri menjadi desa mandiri, kondisi fisik dan pembangunan di Desa Sidoasri terus meningkat pesat. Artinya bahwa semakin kesini semakin dirasakan manfaatnya oleh masyarakat.

Disisi lain yang masih berkaitan, antara periode pertama dan kedua, lebih banyak informan yang menjawab bahwa lebih bagus perubahan dalam masa periode kepemimpinan yang ke dua. Terlebih untuk masalah administrasi di desa, karena selama periode ke dua ini Pak Wiwik lebih banyak tinggal di desa dan banyak melayani masyarakat. berbeda halnya ketika beliua masih menjabat dalam periode pertama dulu, beliau mengurus bisnis / usaha di luar desa dan hal tersebut membuat kesulitan tersendiri bagi warga masyarakat yang berkepentingan dengan Pak Wiwik karena beliau sulit di temui. Saran pembangunan untuk kedepannya ,adalah agar jalan yang sudah ada dirawat dengan baik, karena jalan merupakan infrastruktur paling utama. Hal ini berkaitan juga sebenarnya dengan hasil potensi masyarakat Sidoasri yang seringkali dibawa keluar desa.

Untuk kegiatan desa sendiri, saat ini juga dirasakan telah banyak perubahan yang mengarah kepada perubahan yang lebih baik. Perkembangan pembangunan yang ada di Desa Sidoasri terus mengalami peningkatan, baik secara fisik maupun sosial.Misalnya semakin tertatanya lingkungan desa karena banyak penyuluhan-penyuluhan yang dilakukan. Perkembangan ini diperlihatkan adanya keikut sertaan dalam PKK lingkup RT merupakan kewajiban semua wanita untuk berpartisipasi dalam kegiatan desa.Kegiatan-kegiatan 
penyuluhan yang diadakan oleh desa sendiri ternyata membawa perubahan yang signifikan karena diikuti dengan semakin baiknya mekanisme kerja masyarakat. Misalnya dalam hal bercocok tanam. Warga mampu membedakan bagaimana bercocok tanam yang baik dan mendapatkan keuntungan maksimal.

\section{SIMPULAN}

Adapun poin-poin yang terlihat dari hasil penelitian yang dilakukan diatas ada beberpa temuan yang berkaitan dengan rumusan masalah yang diajukan,

Pertama, ada perubahan yang signifikan dalam pola kepemimpinan yang dijalankan oleh kepala desa. Perubahan tersebut bisa dirasakan pada saat sebelum terjadi pemekaran desa dan pasca pemekaran desa sehingga terbentuk desa baru. Di masa sebelum pemekaran, warga menganggap tidak adanya perhatian kepala desa terhadap warga di wilayah ini sehingga warga mengalami ketidakpercayaan terhadap kepemimpinan kepala desa. Pasca pemekaran ada perubahan yang terjadi terutama dari kepemimpinan kepala desa yang dianggap lebih paham tentang kondisi desa dibandingkan dengan kepa desa sebelumnya. Namun karena masih merupaka desa baru kepala desa masih mencari pola kepemimpinan yang tepat untuk menjalankan roda pemerintahan dan pembangunan desa. Di periode kedua mulai ada titik cerah pola kepemimpinan desa yang dijalankan, sehingga warga menganggap telah terjadi perubahan yang lebih baik dalam kepemimpinan dan pembangunan.

Dalam tata kelola pemerintahan juga terimbas dengan pola kepemimpinan yang dimiliki oleh kepala desa, dengan ketegasan kepala desa dan visi yang jauh dalam melakukan pembangunan desa membuat kerja aparatur desa juga lebih fokus. Hal ini dutunjukkan dengan pelayanan terhadap warga yang semakin lebih baik, sehingga menguntungkan bagi warga.

Kedua, Warga berpendapat ada beberapa perubahan yang signifikan dirasakan ketika periodeperiode kepemimpinan desa tersebut dijalankan. Seperti dalam fasilitas umum berupa infrastruktur desa yang lebih baik dibandingkan sebelum terjadi pemekaran. Di periode pertama pasca pemekaran yang dirasakan oleh warga adalah perubahan infrastruktur desa yang mulai ditata dengan baik seperti jalan desa dan jembatan, walaupun begitu warga merasakan belum dapat aktif terlibat dalam pembangunan desa. Di periode kedua pembangunan yang dirasakan didukung oleh pola kepemimpinan kepala desa yang tegas dan lebih perhatian ke warga, sehingga membuat warga lebih dihargai oleh kepala desa dan merasa di "uwongke" (diorangkan). Hal ini dianggap sangat berarti buat warga.

Ketiga, ada perubahan lain yang dianggap signifikan oleh warga yang dianggap masih perlu diperbaiki seperti masalah kurang berfungsinya lembaga keluarga, lembaga agama yang kurang diperhatikan dan tidak ada sinergi dalam pembangunan desa, masalah moralitas pemuda dan masalah pengembangan potensi desa. Warga berharap masalah-masalah tersebut dapat diselesaikan oleh kepala desa sebagai pemimpin masyarakat

Keempat,sebagai daerah pemekaran Desa Sidoasri menunjukkan sebagai desa yang berhasil dalam melakukan pembangunan. Hal ini menghapus kekhawatiran bahwa pemekaran pada daerah baru akan berdampak pada terhambatnya pembangunan. Faktor penting yang menjadi alasan keberhasilan tersebut adalah pada kepemimpinan desa dan partisipasi warga. 


\section{DAFTAR PUSTAKA}

Asy’ari, Sapari Imam, 1993, Sosiologi Kota dan Desa, Usaha Nasional, Surabaya.

Creswell, John W. 2010, Research Design: Pendekatan Kualitatif, Kuantitatif dan Mixed. Pustaka Pelajar, Yogyakarta.

Davies, Rick dan JessDart, The "Most Significant Change" (MSC) Technique, A Guide do ItsUse, version 1.00, April 2005 (Availableat : www.mande.co.uk/docs/MSCGuide.htm, diakses 20 Januari 2015)

Eko, Sutoro, 2014, Kedudukan, Kewenangan dan Tata Kelola Desa, Forum Pengembangan Pembaharuan Desa (FPPD), Yogyakarta.

Hidayati, Nur, 2014, Modul Panduan Praktis Teknik Most Significant Change (MSC) Untuk Monitoring dan Evaluasi, Resultin Health (RIH), Netherlands.

Matose, F. 2008. Institutional Configurations around Forest Reserves in Zimbabwe: The Challenge of Nested Institutions for Resource Management. Local Environment Vol. 13 no 5, 2008.

Murtiono, Yusuf, Masrukhan, Widuri, Dyah, 2014, Pertangungjawaban Penyelenggaraan Pemerintah Desa, Forum Pengembangan Pembaharuan Desa (FPPD), Yogyakarta.

Rosyadi, Slamet dan Khairu Roojiqien Sobandi, 2014. Relasi Kuasa Antara Perhutani Dan Masyarakat Dalam Pengelolaan Sumberdaya Hutan Di Banyumas: Kepentingan Bisnis VS Community Empowerment, Jurnal KOMUNITAS: International Journal Of Indonesian Society And Culture Volume 6, No 1 (2014).

Suandi, 2014. Hubungan Modal Sosial Dengan Kesejahteraan Ekonomi Keluarga Di Daerah Pedesaan Jambi, Jurnal KOMUNITAS: International Journal Of Indonesian Society And Culture Volume 6, No 1 (2014).

SuHt, Edi, 2010, Membangun Masyarakat Memberdayakan Masyarakat: Kajian Strategis Pembangunan Kesejahteraan Sosial dan Pekerjaan Sosial, Refika Aditama, Bandung. 